\title{
Perceptions of Teachers in the First Years of Primary Education Regarding Socio-Emotional Education and Problem Solving
}

\author{
Alexandra Amadio Belli¹, Ana Lúcia Manrique ${ }^{2}$ \\ ${ }^{1}$ Mathematics Education, Pontifical Catholic University, São Paulo, Brazil \\ ${ }^{2}$ Education, Pontifical Catholic University, São Paulo, Brazil \\ Email: aabelli@terra.com.br, analuciamanrique@gmail.com
}

How to cite this paper: Belli, A. A., \& Manrique, A. L. (2017). Perceptions of Teachers in the First Years of Primary Education Regarding Socio-Emotional Education and Problem Solving. Creative Education, 8, 2134-2146.

https://doi.org/10.4236/ce.2017.813144

Received: September 20, 2017

Accepted: October 27, 2017

Published: October 30, 2017

Copyright ( $) 2017$ by authors and Scientific Research Publishing Inc. This work is licensed under the Creative Commons Attribution International License (CC BY 4.0).

http://creativecommons.org/licenses/by/4.0/

(c) (i) Open Access

\begin{abstract}
In the school context, the development and education of children and adolescents involve inter-relations between emotion, cognition and socialization; in other words, emotional and social skills management cannot be disconnected from student learning. The aim of this study is to analyze teacher training in the early years of Primary Teaching through the reading, analysis and reflection of texts on Socio-emotional Competencies and Problem Solving. Audio recordings were used, along with their transcriptions, with a view to supplying the teachers' words in their entirety, although for the article only extracts that were relevant to the understanding of the problem studied in this research were used. The conclusions indicate that Socio-emotional Education can contribute to the practice of teaching and teacher training. In addition to this, as reported by the teachers participating in the research, with the use of Problem Solving methodology in the teaching of mathematics in the classroom, space and opportunity have been gained for the development of Socio-emotional Competencies with students, improving the management of stress and conflicts in the school environment.
\end{abstract}

\section{Keywords}

Mathematics Education, Socio-Emotional Education, Problem Solving, Socio-Emotional Competencies, Teacher Training, School Environment, Stress and Conflicts, Teacher Education

\section{Introduction}

In the school context, the development and education of children and adoles- 
cents involve inter-relations between emotion, cognition and socialization; in other words, emotional and social skills management cannot be disconnected from student learning. Hofmann \& Asmundson (2008) claim that the teacher who seeks to unite these inter-relations widens their own relations and those of their students; creates affective possibilities between people around them; works in a cooperative way with social and environmental engagement; facilitates a sense of community and social awareness; improves quality of life, as well as academic and professional performance. And other authors point to the direct relation of these inter-relations with the personal and professional success of students (Elias et al., 1997; Fernández-Berrocal \& Aranda, 2008).

Research by Rodrigues, Dias, \& Freitas (2010), a research-intervention regarding interpersonal problem solving in groups of children in the first year of Primary School, demonstrated the need to promote socio-emotional competencies with a view to creating positive functional behavior, indicating an increase in the skills of empathy, assertiveness, civility, responsibility and expression of positive feelings. Work was also carried out with parents and teachers and greater awareness was observed in regard to their educational strategies and management of interdisciplinary behaviors. Thus, the authors indicate that social and emotional competencies can have a preventive character, both as a protection factor for healthy child development, and as a benefit for the practice of teachers and carers.

In this sense, working on social and emotional competencies with students at primary level means teaching them to evaluate, understand, express and control their emotions; and to realize and manage their feelings so as to promote functional behavior that enables them to achieve balanced, integral growth (Rêgo \& Rocha, 2009).

Other authors also state that this work brings results in Primary School, as in the case of research by Cacheiro \& Martins (2012), who found indicators of reduction in anxiety about learning and fear of being exposed to a group, including those students with special educational needs, through the development of social and emotional competencies. During the research, they worked with emotional competency, identifying and regulating emotions, and with this obtained improvements in children's self esteem and self concept. In relation to social competency, they also covered assertiveness and interpersonal conflict solving, contributing to respect for human individuality. They also affirm that it was possible to observe greater parental involvement and participation in their children's education.

Costa \& Faria (2013), through a study carried out with secondary teachers in Portugal with the aim of getting to know their view of the school's role in the promoting the learning of social and emotional competencies, obtained acknowledgement, unanimous among teachers, of the need for education that includes these competencies and how much they influence the academic success of students. In this study, a change in positioning and understanding on the part of 
the students was observed, and they began to have a more critical, interventional, autonomous and responsible attitude, leading to an increase in their self esteem, self confidence and awareness in relation to their studies. In addition, in their analyses, the researchers construct a criticism of school that finds itself, in the contemporary context, increasingly more pressurized regarding positive academic results, thereby failing to respond to the need for the global development of students.

Faced with this context and considering the important role of Mathematics in the development of society, in the daily life of the individual, and concerned about making mathematics teaching more efficient, we inserted as the aim in this study the training of teachers in the first years of Primary school that includes Socio-emotional Competencies and Problem Solving.

In the 1980s, with the possibility of the development of Socio-emotional Competencies in schools, with the construction of different Socio-emotional Education Programs in the world scenario, the discussion on affectivity related to the process of teaching and learning was accentuated. There is thus a reaffirmation regarding the disassociability between culturally constituted affective and cognitive processes, which were discussed at length by Jean Piaget (1896-1980), Lev Semenovich Vigotsky (1896-1934) and Henri Wallon (1879-1962).

To define which Socio-emotional Competencies will be taught in a Socio-emotional Education school program, including mathematics classes, it is necessary to consider the context, the society in which the learning is inserted, taking into account cultural, ethnic, political, economic etc aspects.

For the CASEL Organization (2013), this learning is a continuous process and is developed over several years, in the case of Brazil, beginning at Primary School, extending to Secondary, using explicit lessons that involve not only the school environment but also that of the family and the whole community.

In this way, the socio-emotional competencies learned in class must flow beyond the school limits, must constitute a practice to be used in "real life" (Cohen, 2006; Nation et al., 2003; Weare \& Nind, 2011).

\section{Theoretical Reference}

In the process of schooling a child, it is supposed that innumerable interactions occur, in which affectivity is associated not only with personal relations but also relations with didactic material, with the construction of knowledge and with the physical school space.

In order to understand this process, we consider the definition of affectivity given by Wallon:

It refers to the ability, the disposition of the human being to be affected by the external and internal world through sensations connected to agreeable or disagreeable tonalities. The theory presents three significant, successive moments in the evolution of affectivity. emotion, feeling and passion. The three result from organic and social factors and correspond to different configurations, resulting 
from their integration; in emotions, there is the predominance of physiological activation; in feeling, representational activation; in passion, self-control activation (Mahoney \& Almeida, 2007: 17).

Chacón (2003: 20) while considering McLeod, widens the concept of affectivity on affirming that affection covers non-cognitive competencies, defining it as "an extensive category of feelings and humor (states of spirit)", considering not only emotions, feelings and social skills, but also beliefs, attitudes, values and likes.

Therefore, Wallon and McLeod consider cognition and affectivity as inter-linked parts, and that this connection is corroborated in the constitution and functioning of human intelligence, with affectivity as the dimension greater than the emotional and social aspects covered in our study.

In this context and considering Mathematics Education, we researched studies carried out by Chacón (2003). This author recognizes that, over the years, despite the fact that researchers and educators have acknowledged that emotional aspects influence the quality of teaching and learning, these aspects were left aside and, only from the end of the 1980s, did they begin to have importance in research into Mathematics Teaching Methods.

This new focus on the affective dimension, foreseen in the work of mathematics educator McLeod (1988, 1992, 1994), clearly shows that affective issues have an essential role in the teaching and learning of mathematics, with some of them extremely entrenched in the individual and not easily modified by instruction (Chacón, 2003: 19).

Also in another study, Radford (2015) states that emotions are part of mathematical thinking as long as we consider them as historically and culturally constituted.

[...] from a cultural-historical perspective, emotions are both subjective and cultural phenomena simultaneously; they are entrenched in physiological processes and conceptual and ethical categories through which individuals perceive, understand, reflect, and act in the world. Their subjective-social link is to be found in the double-faced nature of motives, which are always personal and cultural (Radford, 2015: 11).

Making use of the reference to the subjective-social link expressed by Radford, we assert that Socio-emotional

Competencies must be understood as individual skills, which are developed and learned in order to pursue objectives in life.

In our research we adopt studies carried out by the CASEL Organization (2013), which defines and organizes five groups of competencies to be developed, and which are presented in Table 1.

Greenberg et al. (2003) relate that the development of Socio-emotional Competencies is fundamental for the adaptation of the individual to the demands of society; in other words, it contributes effectively to adaptation to the complex needs for the process of development in the human being, thus revealing a way of preventing mental disturbances. When the integral development of the 
Table 1. The Five Social and Emotional Learning Core Competencies, according to CASEL.

\begin{tabular}{cl}
\hline $\begin{array}{c}\text { Groups of } \\
\text { Competencies }\end{array}$ & \multicolumn{1}{c}{ Characteristics } \\
\hline Self-awareness & $\begin{array}{l}\text { The ability to accurately recognize one's emotions and thoughts and their influence on behavior. } \\
\text { This includes accurately assessing one's strengths and limitations and possessing a } \\
\text { well-grounded sense of confidence and optimism. } \\
\text { The ability to regulate one's emotions, thoughts, and behaviors effectively in different situations. }\end{array}$ \\
Self-management & $\begin{array}{l}\text { This includes managing stress, controlling impulses, motivating oneself, and setting and } \\
\text { working toward achieving personal and academic goals. }\end{array}$ \\
Social awareness & $\begin{array}{l}\text { The ability to take the perspective of and empathize with others from diverse backgrounds } \\
\text { and cultures, to understand social and ethical norms for behavior, and to recognize family, } \\
\text { school, and community resources and supports. }\end{array}$ \\
Relationship skills & $\begin{array}{l}\text { The ability to establish and maintain healthy and rewarding relationships with diverse individuals } \\
\text { and groups. This includes communicating clearly, listening actively, cooperating, resisting inappropriate } \\
\text { social pressure, negotiating conflict constructively, and seeking and offering help when needed. }\end{array}$ \\
Responsible & $\begin{array}{l}\text { The ability to make constructive and respectful choices about personal behavior and social } \\
\text { interactions based on consideration of ethical standards, safety concerns, social norms, } \\
\text { the realistic evaluation of consequences of various actions, and the well-being of self and others. }\end{array}$
\end{tabular}

Source: (CASEL, 2013: 9).

individual is proposed, one sees the promotion of mental health, which according to the World Health Organization is "one of the greatest public health concerns at world level" which according to the World Health Organization, in 2004 , is "one of the greatest public health concerns at world level" (Coelho et al., 2016: 61).

On the other hand, nowadays, the teaching of Problem Solving considers students "as active participants, problems as precise, well defined instruments and the activity of problem solving as a complex simultaneous coordination of various levels of activity" (Onuchic, 1999: 203). This work's proposal, using Problem Solving as a methodology in teaching mathematics, was influenced by constructivist theories, which emphasize the role of the student in the construction of their own knowledge.

According to Carneiro (2015), problem solving as a teaching methodology in Mathematics Education is supported by a sequence which is the inverse of the traditional manner (definition, property, exercise and problems), "it begins with a problem, followed by definition, property, exercises and a proposal for new problems" (Carneiro, 2015: 190). With this focus, the problem is seen not as a way of exercising a concept but as a proposal for the construction of mathematical concepts (Neves, Costa, \& Kato, 2014).

According to Romanatto (2012), teaching mathematics through Problem Solving proposes the development of such abilities and social skills as autonomy, initiative, creativity and also develops abilities in reading, critical analysis, text interpretation, reasoning, projection of virtual relations, mental representation and transformation. When working with a problem is proposed, the central objective is to motivate an investigative attitude, not simply to solve the problem, 
find an answer, "the focus should not be centered on 'finding the right answer' but on understanding and comprehending what is being asked" (Lima \& Manrique, 2010: 165).

\section{Method}

In this work, we proposed that participating teachers should read, discuss and analyze two texts, one on Socio-emotional Education (CASEL, 2013) and the other on Problem Solving (Lima \& Manrique, 2010). The reflections of these teachers were to question their teaching practices.

Problem Solving was proposed with the intention of Socio-emotional Education being developed simultaneously with the learning of mathematics. And the text on Socio-emotional Competencies was to promote a reflection on the limits and possibilities of socio-emotional learning in classrooms.

The subjects of this research were three teachers who teach mathematics to students in the early years of Primary Education in a Municipal School in the city of São Paulo, a heterogeneous group in terms of age, sex and professional experience, but all have experience in public and private schools. So as to preserve the identity of the participating teachers, the following denominations are used: Maria (teacher 1), João (teacher 2) and Carmem (teacher 3).

Two meetings were held to read and discuss each selected text. These meetings were recorded and the recordings were transcribed, with a view to supplying the teachers' words in their entirety, although for the article only extracts that were relevant to the understanding of the problem studied in this research were used.

\section{Results}

The perceptions of the teachers regarding Socio-emotional Education and Problem Solving Methodology were the result of reading and discussing texts, establishing a relation with a particular school reality in the south zone of São Paulo and the role of teachers in this context.

We began with a text on Socio-emotional Education when João immediately, in a moment of outburst, expressed the opinion "[...] the psychology of the teacher is never worked on", revealing how important and fundamental he considers the development of social and emotional competencies to be in the process of continued teacher training, as this theme is not touched on at university.

Thus for him "Working on the socio-emotional aspect is perhaps the most important of all, both for the teacher and the student” (João), because it can contribute in the practice of teaching and in the process of learning.

Two of the teachers claim never to have thought about this subject, but showed involvement with this question in group activities in the classroom and also in the way solving conflicts between students is conducted.

It is when reading about the first competency group, called Self-awareness, 
that Carmen points to the need to name emotions and recognize them and consequently generate behavior that is more appropriate and less damaging to the school environment.

The ability to accurately recognize one's emotions and thoughts and their influence on behavior. This includes accurately assessing one's strengths and limitations and possessing a well-grounded sense of confidence and optimism (CASEL, 2013: 9).

Student self-image, according to João, enters into conflict with that of teachers, for the students are from an extremely needy, violent community, with very different values. "They already see us as being at a different level, which creates a very great distance." Even so, the teachers believe in the possibility of introducing and developing the socio-emotional competencies "that everyone needs to live in society"(Carmem).

On reading about self-management the teachers mention the great need their students have to develop inhibitory control, to learn to plan their actions and establish various strategies to achieve targets and solve problems. "[...] thinking before acting [...] not everything turns into a fight, physical fight"(Carmem).

The ability to regulate one's emotions, thoughts, and behaviors effectively in different situations. This includes managing stress, controlling impulses, motivating oneself, and setting and working toward achieving personal and academic goals (CASEL, 2013: 9).

João explains how this practice brings benefits to everyone, telling of the case of a student who asked for meditation (as taught previously by the teacher) to calm the class down. "She asked me, saying that it was through meditation that they would calm down and would also go back to having that good feeling because she said that when she relaxes she feels something so pleasurable. Immediately, Maria also joined in, affirming that self management brings the well-being necessary for learning, "[...] my body also reacts differently".

Following on from this, João concluded that developing self-awareness and self-management is indispensable for the mental health of teachers and consequently that of their students. Learning emotional management, not only recognizing, naming emotions but knowing how to deal with them, favors assertive, appropriate behavior. He relates below a situation in which he felt the lack of these competencies:

The class were screaming incessantly, the teaching assistant came into the classroom to see if I wanted to leave, the room was out of control and everyone was screaming and one female student was swearing at me [...]. At a certain moment, naturally, I got involved with the whole thing, because I was up against the wall, with several children around me, and after a while I ended up speaking inappropriately, in a prejudiced way, getting everything off my chest. Because there comes a time when you can't take it any longer, you over-react. Nobody can help, there's nobody to go to (João).

Regarding reflections on social awareness, João mentions the importance of 
partnership with the family in schooling, saying that "the family has a very important role in all of this" and the extent to which this does not happen in this community; on the contrary, very often families end up deconstructing the work done by teachers and all this has a direct relation to learning.

And it's difficult, and you don't realize it. Sometimes you're talking, and you notice in the look of that child that they could slap you in the face and say to you that nothing you say to them is important, because this is not what they live, this is not what their family teaches them, this is not what the family wants because sometimes it is not what the child themselves wants. And you say 'My god how do we proceed? You begin to become aware, to be moved, to plant that little seed of something really good. And sometimes you catch yourself thinking about how to do that, specifically for this community that we cater to [...] (Carmem).

Maria declares at this moment of the discussion that Socio-emotional Competencies are necessary and present at every moment, "[...] you teach emotional skills the whole time, in mathematics, in Portuguese, in science, in everything”. However, João argues that he often doesn't find space to teach and develop these competencies, due to the presence of extremely undisciplined students, "[...] it depends on some individuals who exist, who are in the classroom, who often destabilize the environment [...] "(João).

In addition to these arguments, Carmen also refers to certain occurrences and emotional aspects in the family environment in the process of teaching and learning, stating that ' $[$...] there's something else that's interfering so much at home" (Carmem).

The teachers also state that the concepts of empathy, friendship, respect for others, are very difficult to be appropriated by the children of this community, despite the constant work done on them, including actions and practices inside the school.

The ability to take the perspective of and empathize with others from diverse backgrounds and cultures, to understand social and ethical norms for behavior, and to recognize family, school, and community resources and supports (CASEL, 2013: 9).

They relate that there is a great deal of wear and tear on the part of school professionals, for they are constantly exposed to situations of aggression and often end up losing control.

According to these teachers, the absence of social awareness in these children, their families and some teachers is very clear, when the school is assailed by innumerable thefts of teaching and educational material, by acts of vandalism and even kidnapping of teachers, and no measures are taken nor any changes announced. The relation of disrespect towards others is such that it extends beyond relations between students, affecting all the professionals that work in the school space.

Science and geography rooms with a television that teachers obtained through a project that they did themselves are without keys, left open, plundered(Maria). 
Like today, one teacher found her cupboard broken into, with nothing inside, and that's the fourth time this year (João).

In a further declaration, Carmem affirms that '[...] the teaching course prepares us theoretically to teach, but we weren't prepared emotionally to deal with so many differences and situations [...]".

On reading about relationship skills, the teachers constructed the idea that Socio-emotional Education needs to be considered in every school year, by all professionals involved in the school, throughout the school year and that the competencies developed should also include the families.

The ability to establish and maintain healthy and rewarding relationships with diverse individuals and groups. This includes communicating clearly, listening actively, cooperating, resisting inappropriate social pressure, negotiating conflict constructively, and seeking and offering help when needed (CASEL, 2013: 9).

The situation of disregard for the role of the school is very great to the point of mentioning that some students keep their backpacks on all the time, with the intention of finding a way to leave the school at any given moment.

They come with a bag and they don't take it off their back and are ready to leave. They go at any given moment. Or they run away, they escape through the holes in the school fence or jump the wall (João). Or they simply go into the Office, press the button to open the gate and leave (Carmem).

Maria relates that her first-year students are, for the most part, well-behaved, though what she has noted in this school is that with the passing of the school years, this characteristic, mainly from the third year on, is lost. "My classroom is very welcoming, but, with the passing of time, I know that this will not last, the seed that I planted will die, it will dry up and die." They reaffirm, therefore, the need for Socio-emotional Education up to secondary School, to include the community as well.

The teachers express their awareness that it does not depend exclusively on their actions to change such a school scenario and, incidentally, they defend the idea of social transformations and new public policies that place Education on their list of priorities.

And, finally, with the discussions on the theme of responsible decision making, the difficulty in working with these students was declared, for they do not feel they belong to a country, through not having feeling of nation they therefore have a very limited cultural view, restricted to that community, that neighborhood.

The ability to make constructive and respectful choices about personal behavior and social interactions based on consideration of ethical standards, safety concerns, social norms, the realistic evaluation of consequences of various actions, and the well-being of self and others (CASEL, 2013: 9).

Carmem proposes a reflection for the responsible authorities: the possibility of the creation of socio-emotional or socio-educational projects to work with those children who stay in school full time, instead of leaving them with no activities, abandoned in the sports area. 
In the discussion on the Problem Solving text, at first the teachers presented the impact that family dysfunction has on learning. How much '[...] they follow the example of their parents, which are often negative examples in terms of behavior"(João). Therefore some examples of family problems were presented and how much these children are faced with the need and readiness to solve them.

Another situation brought up by the teachers in the discussion is the lack of persistence and resilience in the students in the face of challenges, difficulties, for the students retreat and switch off from the problem situation, needing a lot of encouragement and mediation to resume the question "And so I realize that they tire easily. If you propose something that has an obstacle, that dispels them. It seems that they've been automatically unplugged from the socket "(João).

At that moment there was further mention of the little or no family involvement in school activities, since there are countless cases of homework not done, which need the participation of some family member. "Few responded to the research, because the mother and father never see their child's notebook" (João). "What we ended up noticing is that they only touch their notebooks at school and with us" (Carmem). "I think we would need to teach the mothers [...] Have classes for the mothers" (Maria). They also relate that many fathers and mothers are not literate, which makes this relationship difficult. According to João, there are cases of mothers who go to parent meetings just so that teachers can read their children's reports to them, or just to arrange some form of communication because they are illiterate.

\section{Conclusion}

By considering the teacher as a mediator of the processes of their students' learning and through the perception of teachers that the teaching of mathematics is processed from the problem situation of the reality of their students and the context into which they are inserted, we can hereby state that the contributions of studies on Socio-emotional Competencies and Problem Solving in teacher training are innumerable.

On acquiring this knowledge, the teacher manages to facilitate and increase their teaching practice, contributing to the comprehension, understanding and application of these concepts and mathematical content.

The teacher becomes motivated regarding their work, for they will have resources to contribute effectively in the whole education of the students, valuing cognitive, emotional, ethical and social questions, knowing how to relate them and introduce them in a classroom context. They will also be able to link this learning to outside the classroom, extending it to the community. It is also from this knowledge that the teacher can encourage and motivate an investigative attitude in their students, demonstrating the importance of the role of the student in the construction of their own knowledge, valuing the initiative and engagement of the students when faced with problem situations.

And, first and foremost, the teacher will use this knowledge as a preventive measure regarding mental health, not only for themselves but also for their stu- 
dents.

Given the school reality presented by the perception of teachers at a municipal school in the south zone of São Paulo, where they lack a welcoming environment, direction, knowledge, practices and new public policies, we can duly declare the importance of handling emotional management, giving the teacher recognition, validation and evaluation of their emotions, strengths and limitations within the practice of their work. In addition, they can develop confidence and optimism in their actions and possible changes in their educational practices. At the same time, they can manage stress better and direct their focus to their personal, professional and academic objectives. It is with the development of social awareness, empathy, that a better perception of reality is verified, respecting and accepting social norms and ethics of human behavior.

This can thus facilitate the establishment and maintenance of healthy relationships between students, educational professionals and the community, developing cooperation, resistance to inappropriate social pressure and learning to negotiate conflicts assertively, with a view to promoting the their own welfare and that of others.

Therefore, to propose Socio-emotional Education in mathematics classes, to be developed and taught in situations of Problem Solving and also to incorporate it in the teacher education of the teachers brings together the emotions, feelings and social skills of mathematics, that is, it indicates the relationship between affectivity and cognition in a school context.

\section{Acknowledgements}

The authors thank the CNPQ for their financial support.

\section{References}

Cacheiro, C. M., \& Martins, M. J. D. (2012). Promoção de competências sócio-emocionais em crianças do ensino básico. [Promotion of Socio-Emotional Competences in Children at Primary School.] Revista Galego-protuguesa de Psicoloxia e Educación, 20, 155-168. Disponível em:

http://ruc.udc.es/dspace/bitstream/2183/12108/1/RGP_20_2012_art_10.pdt. Acesso em: 10 out. 2015.

Carneiro, R. F. (2015). Formulação e resolução de problemas em aulas de matemática de um $6^{\circ}$ ano do ensino fundamental. [Formulation and Problem Solving in the Mathematics Classes of a 6th Year of Elementary School.] Revista Paranaense de Educação Matemática, 4, 188-205.

CASEL-Collaborative for Academic, Social, and Emotional Learning (USA) (Org.) (2013). CASEL Guide Effective Social and Emotional Learning Programs: Preschool and Elementary School Edition. Chicago: Ksa-Plus Communications, Inc., 80 p. Disponível em: <http://www.CASEL.org/guide>. Acesso em: 30 maio 2015.

Chacón, I. M. G. (2003). Matemática emocional: Os afetos na aprendizagem matemática. [Emotional Mathematics: The Affects in Mathematical Learning.] Porto Alegre: Artmed, $255 \mathrm{p}$.

Coelho, V. A. et al. (2016). Programas de intervenção para o desenvolvimento de 
competências socioemocionais: Uma revisão crítica dos enquadramentos SEL e SEAL. [Intervention Programs for the Development of Socio-Emotional Competences: A Critical Review of the SEL and SEAL Frameworks.] Análise Psicológica, 34, 61-72. ISPA-Instituto Universitário. https://doi.org/10.14417/ap.966

Cohen, J. (2006). Social, Emotional, Ethical, and Academic Education: Creating a Climate for Learning, Participation and Democracy, and Well-Being. Harvard Educational Review, 76, 201-237. https://doi.org/10.17763/haer.76.2.j44854x1524644vn

Costa, A., \& Faria, L. (2013). Aprendizagem Social e Emocional: reflexões sobre a teoria e a prática na escola portuguesa. [Social and Emotional Learning: Reflections about Theory and Practice in the Portuguese School.] Análise Psicológica, 31, 407-424. Disponível em: http://repositorio.ispa.pt/bitstream/10400.12/3392/1/AP_31_407-424.pdf. Acesso em: 20 out. 2015.

Elias, M. J. et al. (1997). Promoting Social and Emotional Learning: Guidelines for Educators. Alexandria: Association for Supervision and Curriculum Development, $163 \mathrm{p}$.

Fernández-Berrocal, P., \& Aranda, D. R. (2008). La Inteligencia emocional em la Educación. [Emotional Intelligence in Education.] Revista Electrónica de Investigación Psicoeducativa, 6, 421-436. Disponível em:

http://www.habilidadesparaadolescentes.com/archivos/2008_Inteligencia_Emocional_ Educacion.pdf

Greenberg, M. T. et al. (2003). Enhancing School-Based Prevention and Youth Development through Coordinated Social, Emotional, and Academic Learning. American Psychologist, 58, 466-474. American Psychological Association (APA).

https://doi.org/10.1037/0003-066X.58.6-7.466

Hofmann, S. G., \& Asmundson, G. J. G. (2008). Acceptance and Mindfulness-Based Therapy: New Wave or Old Hat? Clinical Psycology Review, Boston, 28, 1-16. http://contextualscience.org/files/hofmann_asmundson_2008.pdf

Lima, C. A. R., \& Manrique, A. L. O. (2010). Caráter investigativo dos problemas de matemática propostos para crianças de 3 a 6 anos. [The Investigative Character of the Mathematical Problems Proposed for Children Aged 3 to 6 Years.] Educação Marista, Curitiba, 10, 163-171.

Mahoney, A. A., \& Almeida, L. R. (2007). A dimensão afetiva e o processo ensinoaprendizagem. [The Affective Dimension and the Teaching-Learning Process.] In A. A. Mahoney, \& L. R. Almeida (Eds.), Afetividade e aprendizagem: Contribuições de Henri Wallon [Affectivity and Learning: Contributions by Henri Wallon.] (pp. 15-24, Cap. 1). São Paulo: Edições Loyola.

Nation, M. et al. (2003). What Works in Prevention: Principles of Effective Prevention Programs. American Psychologist, 58, 449-456.

Neves, K. C. R., Costa, L. P., \& Kato, L. A. (2014). A metodologia da resolução de problemas no processo de ensino e de aprendizagem nos quartos e quintos anos do ensino fundamental. [The Methodology of Problem Solving in the Process of Teaching and Learning in the Fourth and Fifth Years of Elementary School.] Revista Paranaense de Educação Matemática, Campo Mourão, 3, 73-99.

Onuchic, L. R. (1999). Ensino-Aprendizagem de Matemática através da Resolução de Problemas. In M. A. V. Bicudo (Ed.), Pesquisa em Educação Matemática: Concepção e Perspectiva. [Mathematics Teaching and Learning through Problem Solving.] (Cap. 12, pp. 199-218). São Paulo: Unesp.

Radford, L. (2015). Of Love, Frustation, and Mathematics: A Cultural-Historical Approach to Emotions in Mathematics Teaching and Learning. In B. Pepin, \& B. 
Roesken-Winter (Eds.), From Beliefs to Dynamic Affect Systems in Mathematics Education: Exploring a Mosaic of Relationships and Interactions (Cap. 2, pp. 25-49). Springer International.

Rêgo, C. C. A. B., \& Rocha, N. M. F. (2009). Avaliando a educação emocional: Subsídios para um repensar da sala de aula. [Evaluating the Emotional Education: Subsidies to Rethink the Classroom.] Ensaio: Avaliação e Políticas Públicas em Educação, 17, 135-152.

Rodrigues, M. C., Dias, J. P., \& Freitas, M. F. R. L. (2010). Resolução de problemas interpessoais: Promovendo o desenvolvimento sociocognitivo na escola. [Interpersonal Problem-Solving: Promoting Socio-Cognitive Development in School.] Psicologia em Estudo, Maringá, 15, 831-839. https://doi.org/10.1590/S1413-73722010000400019

Romanatto, M. C. (2016). Resolução de problemas nas aulas de matemática. [Problem Solving in Mathematics Classes.] Revista Eletrônica de Educação, São Carlos, 6, 299-311. http://www.reveduc.ufscar.br

Weare, K., \& Nind, M. (2011). Mental Health Promotion and Problem Prevention in Schools: What Does the Evidence Say? Health Promotion International, 26, i29-i69. 